\title{
STUDIES ON THE EFFECTS OF SUCCINYLCHOLINE UPON THE CIRCULATION OF THE ANAESTHETIZED DOG
}

\author{
KenNeth Macrae Leighton, M.B., Ch.B., F.R.C.P.(c)*
}

GeNeral anaesthetic agents may have profound cardiovascular effects. Some of the circulatory changes which accompany general anaesthesia may, however, be related to agents other than general anaesthetics. Such drugs may have been employed as adjuvants in the production of general anaesthesia or in the facilitation of its maintenance.

Individual organs and tissues vary in the degree or even in the nature of the change shown by their vessels following the administration of any given agent. It is possible for splanchnic blood flow, for example, to decrease at the same time that cutaneous or skeletal muscle flows are increasing.

The effect of a drug upon intra-organ flow is still more uncertain. Total blood flow to an organ might increase at a time when capillary or nutrient flow is actually diminishing. This condition may follow the opening up of arteriovenous anastomotic channels with a consequent shunting of blood away from the capillary circulation.

In the investigation of this problem, it is obviously desirable that total (gross) flow, and capillary (or nutrient) flow to an organ be capable of simultaneous measurement.

The measurement of blood flow is a technique fraught with problems. According to Bellville and Weaver ${ }^{1}$ at least 30 different methods exist for measuring blood flow. Some of the problems are reviewed by Barnett and Jackson ${ }^{2}$ and also in the published Proceedings of an International Conference held in Glasgow (1967) to consider blood flow through organs and tissues. ${ }^{3}$

The present investigation, part of a study of the effects of general anaesthesia upon tissue and organ blood flows, was undertaken following an observation made in animals to whom succinylcholine had been administered in order to facilitate endotracheal intubation.

The injection of succinylcholine in these animals was followed by a consistent fall in renal blood flow. It was decided to investigate possible mechanisms for this fall.

\section{Experimental Method}

Both electromagnetic and ultrasonic (Doppler) flow measuring devices were used in the experiments (vide infra). In certain experiments flow probes were

*Department of Anaesthesia, Vancouver General Hospital, Lecturer, Department of Pharmacology, University of British Columbia, Vancouver 8, B.C.

Work performed with the assistance of a grant-in-aid of research by the British Columbia Heart Foundation. 
chronically implanted. The remainder were acute experiments and the animals were sacrificed.

Twenty-two mongrel dogs were employed (average weight $15 \mathrm{~kg}$ ). Anaesthesia was maintained with a mixture of nitrous oxide and oxygen ( $\left(\frac{3}{3}: \frac{1}{3}\right)$ to which halothane was added from a Fluotec Mark 2 vaporiser. Concentrations (as metered by the vaporiser) varied from 1 per cent to 2 per cent. Prior to the administration of this anaesthetic mixture, the animals underwent endotracheal intubation (through the mouth). This procedure was facilitated by the administration of succinylcholine ( $1.0 \mathrm{mg}$ per $\mathrm{kg}$ ) or thiopentone $(20.0 \mathrm{mg}$ per $\mathrm{kg})$. Ventilation was controlled by a Bird Mark 8 Ventilator-assistor.

Cannulae were inserted into the femoral artery and vein to permit arterial blood sampling and pressure recording (Statham) and the intravenous administration of drugs.

Arterial blood was sampled for the determination of $\mathrm{Po}_{2}, \mathrm{PCO}_{2}$ and $\mathrm{pH}$ (Radiometer Acid-Base Analyzer type PHM71). Blood gases were maintained within the range $\mathrm{Po}_{2}>100 \mathrm{~mm} \mathrm{Hg}$, $\mathrm{PCO}_{2} 25-35 \mathrm{~mm} \mathrm{Hg}$ and $\mathrm{pH} 7.35-7.46$ by controlling ventilation or, where occasion demanded, by the intravenous administration of sodium bicarbonate.

The thorax was opened through an incision in the third left intercostal space or, in some acute experiments, by means of a sternal splitting, mid-line incision.

The left renal artery was exposed, through an incision in the flank, employing an extraperitoncal approach.

A flow probe of either electromagnetic type (Statham) or ultrasonic (Doppler) type was placed around the ascending aorta as close as possible to the heart and a probe of similar type was placed around the exposed renal artery.

Both flow probes were connected to flow meters which, in turn, provided signals for write-out on a Grass (Model 7) polygraph recorder.

The animal was placed on a warming blanket (Gorman-Rupp) (Figure 1).

\section{A. Experiments shouing the effect of succinylcholine on cardiac output, arterial} blood pressure and renal blood flow

Succinylcholine ( $4.0 \mathrm{mg}$ per $\mathrm{kg}$ ) was injected intravenously under the experimental conditions described above. A standard volume of injection and saline flush (total $5.0 \mathrm{ml}$ ) were employed. A similar volume of saline injection was employed as a control.

The injection of succinylcholine resulted in a fall in arterial blood pressure, a fall in renal blood flow and generally, no change in cardiac output. The duration of this response to succinylcholine was of the order of 30 to 40 seconds. In several cases a rise in cardiac output was observed but on no occasion did output fall.

Both arterial blood pressure and renal blood flow showed a quick return to pre-injection levels. This return was followed by an overshoot when both pressure and flow attained levels which were greater than those prior to the injection of succinylcholine.

During the compensatory return of arterial blood pressure and, to some extent, during the overshoot period, there was some increase in heart rate. No period of bradycardia was observed (Figure 2). 


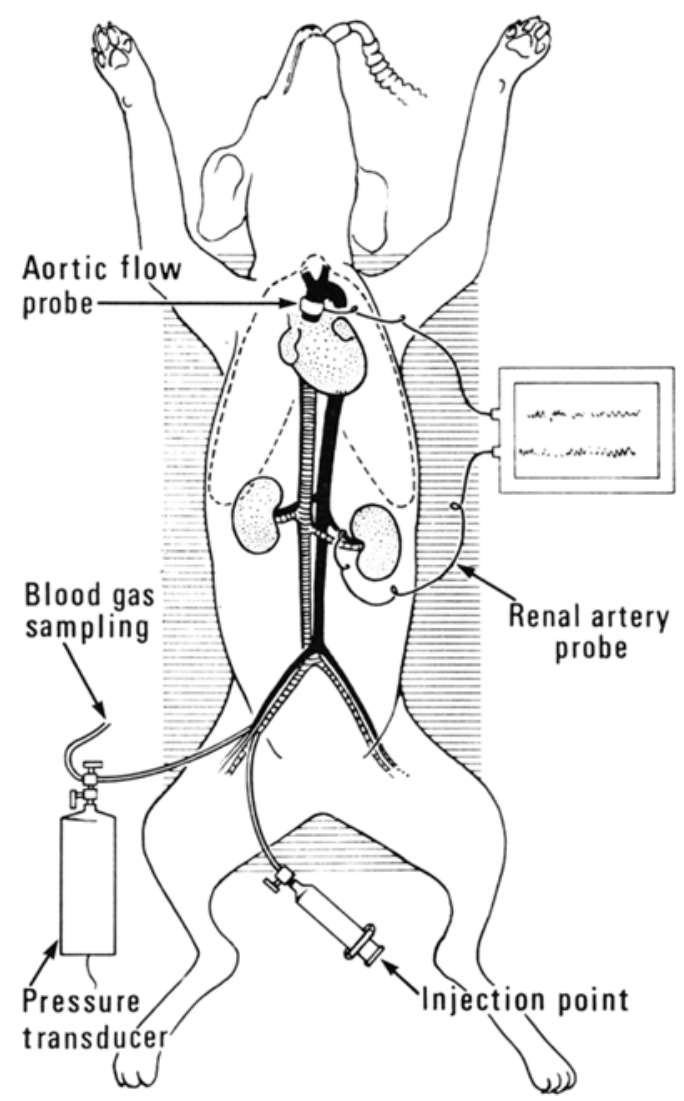

Figure 1. Diagrammatic representation of surgical preparation.

B. Experiments showing the effect of prior administration of atropine upon the previously observed effect of succinylcholine

A succinylcholine response was obtained (as described above).

Atropine sulphate $(0.1 \mathrm{mg})$ was administered intravenously.

Succinylcholine $(4.0 \mathrm{mg}$ per $\mathrm{kg}$ ) was repeated, and it was observed that all the previously recorded changes in arterial blood pressure and renal blood flow were absent (Figure 3).

C. Experiments showing the effect of alpha and beta adrenergic blockade upon the previously observed response to succinylcholine

A succinylcholine response was obtained $(4.0 \mathrm{mg}$ per $\mathrm{kg}$ ) and noradrenaline (1.0 $\mu \mathrm{g}$ per $\mathrm{kg}$ ) was injected intravenously. An increase in arterial blood pressure was noted.

Phenoxybenzamine ( $10 \mathrm{mg}$ per $\mathrm{kg}$ ) was administered and (after a 20 minute waiting period) a second injection of noradrenaline ( $1.0 \mu \mathrm{g}$ per $\mathrm{kg})$ was observed to have no pressor action. 
KENNETH MACRAE LEIGHTON: EFFECTS OF SUCCINYLCHOLINE ON CIRCULATION 103

Doppler

\section{SUCCINYLCHOLINE RESPONSE}

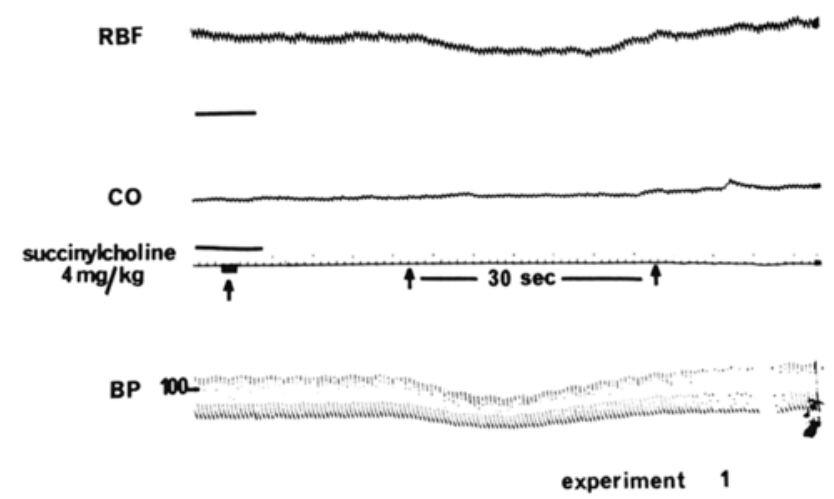

FIGURE 2. Succinylcholine response. Showing initial fall and secondary rise in renal blood flow and arterial blood pressure following the intravenous renal blood flow and arterial blood pressure following the intravenous administration of succinylcholine (4.0 $\mathrm{mg} / \mathrm{kg}$ ). Note cardiac output remains unchanged.

CO

succinylcholine $4 \mathbf{m g} / \mathbf{k g}$

$+$

RBF

BP

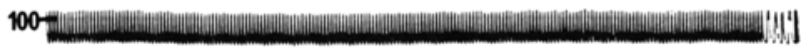

EMF

experiment 2

Figure 3. Effect of atropine $0.1 \mathrm{mg}$. Showing absence of response to succinylcholine. 


\section{ALPHA AND BETA BLOCKADE}

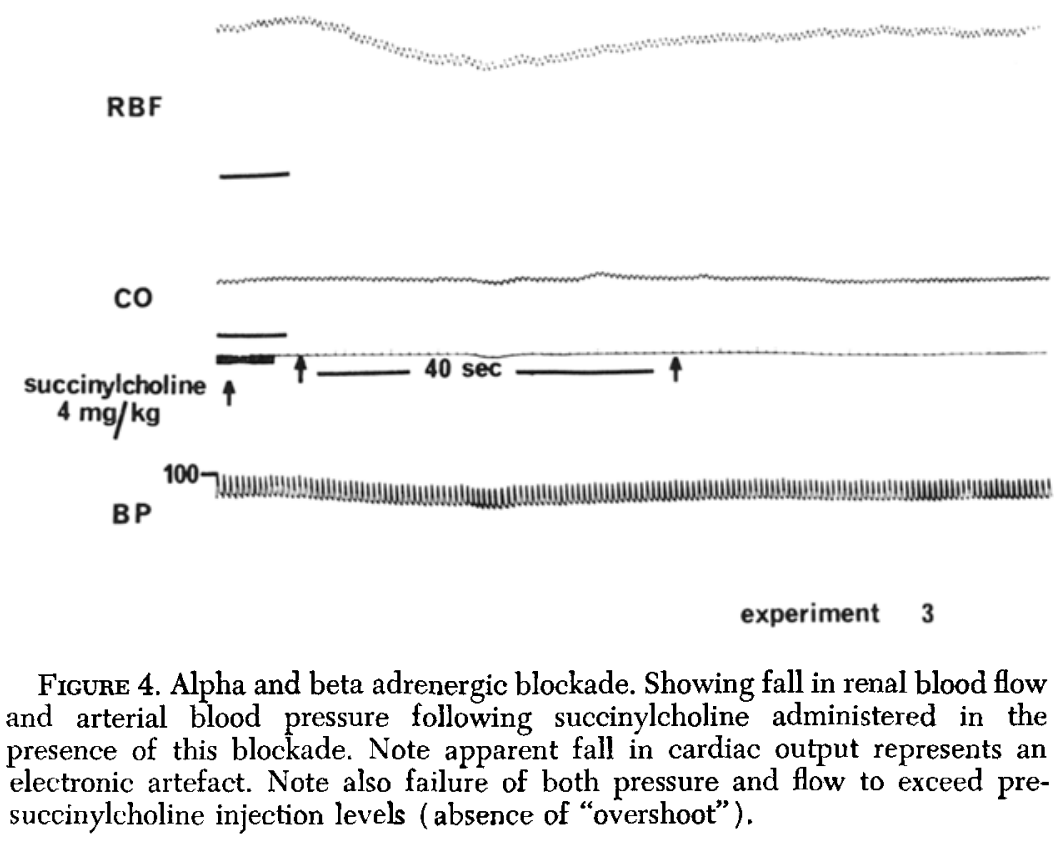

Isoprenaline $(0.5 \mu \mathrm{g}$ per $\mathrm{kg})$ was injected and an increase in heart rate observed.

Propranolol $(0.25 \mathrm{mg}$ per $\mathrm{kg})$ was injected and a second isoprenaline injection ( $0.5 \mu \mathrm{g}$ per $\mathrm{kg}$ ) was noted to be without effect.

Succinylcholine ( $4.0 \mathrm{mg}$ per $\mathrm{kg}$ ) was now administered. Arterial blood pressure and renal blood flow both fell. The subsequent rise in both measurements failed to show an overshoot to levels greater than those obtaining prior to the injection of succinylcholine (Figure 4 ).

D. Experiments showing the effect of vagal ganglionic blockade upon the previously observed response to succinylcholine

A succinylcholine response to the standard dose was obtained.

The right vagus nerve was exposed in the neck and stimulated electrically (Tektronix type 114 Pulse generator). The stimulus was adjusted to produce momentary cardiac standstill. (Typical settings were 3 to 6 volts, peak to peak, 10.0 msec period, square wave.)

Hexamethonium ( $10 \mathrm{mg}$ per $\mathrm{kg}$ in $50 \mathrm{ml}$ normal saline) was administered over a 30-minute period. Vagal stimulation (as above) now failed to arrest the heart's action.

The response to the standard $(4.0 \mathrm{mg}$ per $\mathrm{kg}$ ) dose of succinylcholine given at this point was quite unchanged from that observed prior to the administration 


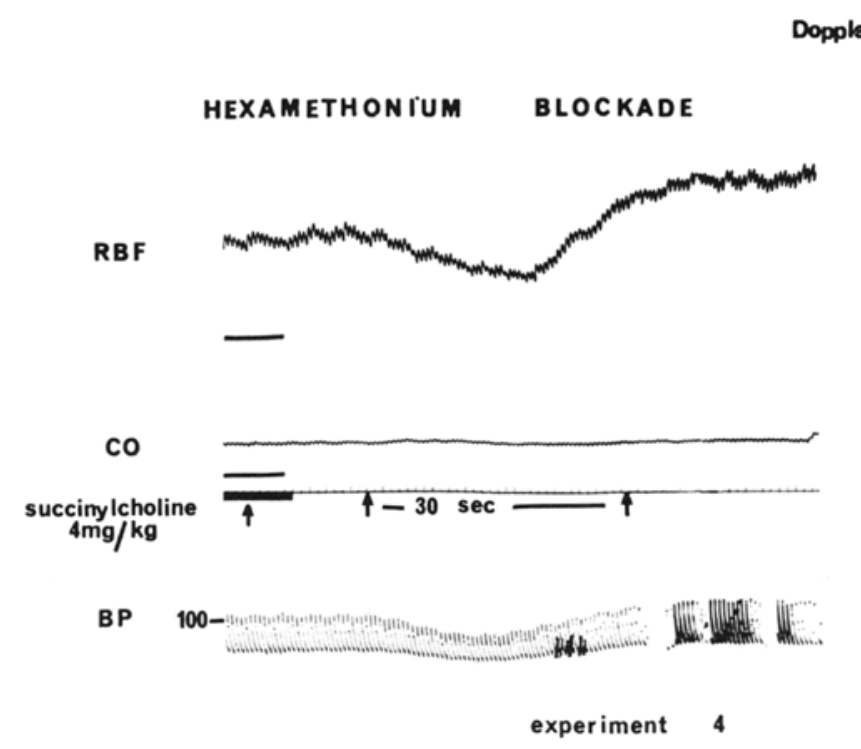

FIGURE 5. Hexamethonium ganglionic blockade. Showing marked response to succinylcholine by renal blood flow and arterial blood pressure only. Note marked "overshoot" of both pressure and flow in comparison with presuccinylcholine injection levels.

of succinylcholine except for the degree of overshoot observed in renal blood flow which, in this instance, was marked (Figure 5).

\section{Discussion}

The measurement of blood flow through any given vessel should involve no distortion of the vessel under investigation. Distortion may be intra-luminal or extravascular. The insertion of any device such as a cannula within the lumen of a vessel will produce some flow distortion as a result of vascular trauma and also by diminishing or otherwise altering the lumen. ${ }^{1}$

Devices are available for the direct measurement of blood flow and which produce a minimal degree of vascular distortion. These devices can be applied to the exterior of suitably sized blood vessels."

One such flow measuring device is the electromagnetic flow probe. The action of this probe is based upon Faraday's Law of Electromagnetic Induction. ${ }^{2}$ This states that a conductor (in this instance, blood) which moves through a magnetic field induces an electromotive force proportional to the velocity of the conductor (Figure 6).

Ultrasonic measuring devices are also available for the measurement of blood flow. Once such device makes use of the shift in frequency of ultrasonic signals reflected by particles in a moving stream (Doppler effect) (Figure 7).

Although some of the experiments described above were conducted using an electromagnetic flow probe, the majority were performed with an ultrasonic probe, the preferred tool. The electromagnetic flow probe was used in conjunction 


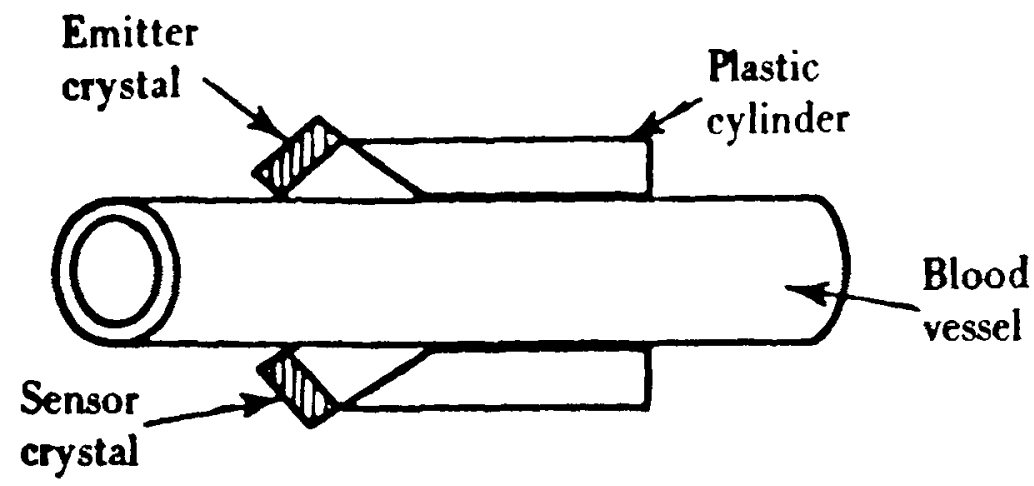

Figure 6. Electromagnetic flow probe. Schematic representation demonstrating the principle of electromotive force induction by the movement of a conductor (blood) through a magnetic field. (Reproduced from Barnett, G. O. and Jackson, W. D. Measurement of instantaneous blood flow. In Friedberg, Stratton Inc., New York 1963. pp. 207-220. By permission).

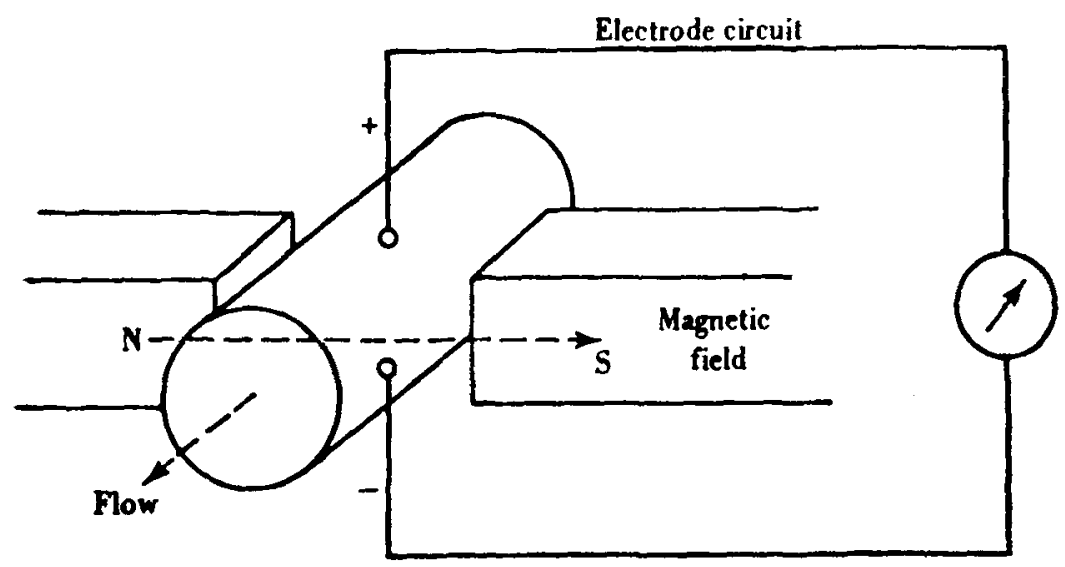

Figure 7. Doppler ultrasonic flow probe. Schematic representation demonstrating the principle of action. Blood flows from left to right in this diagram (See text). (Franklin, D. L. et al. Medical Research Engineering (vol. 5, 1966). Reprinted by permission.

with a Statham M4000 electromagnetic flow meter and the ultrasonic flow probe and meter were produced and supplied by Parks Electronics of Beaverton, Ore. (Figure 8).

The advantages and disadvantages of both varieties of flow probes have been summarised by Belville and Weaver. ${ }^{1}$ The most cogent arguments against the use of the electromagnetic device are base line drift and the problem of obtaining a zero flow recording.

The circulatory effects of succinylcholine in man are stated ${ }^{5}$ to be the production of bradycardia and hypotension (enhanced by cyclopropane and halothane). This initial response is said to be followed by tachycardia and hypertension. The latter effects are thought to be due to autonomic ganglionic stimulation. Ultimately, a ganglionic block is said to develop as a result of increasing the dose of succinylcholine. 

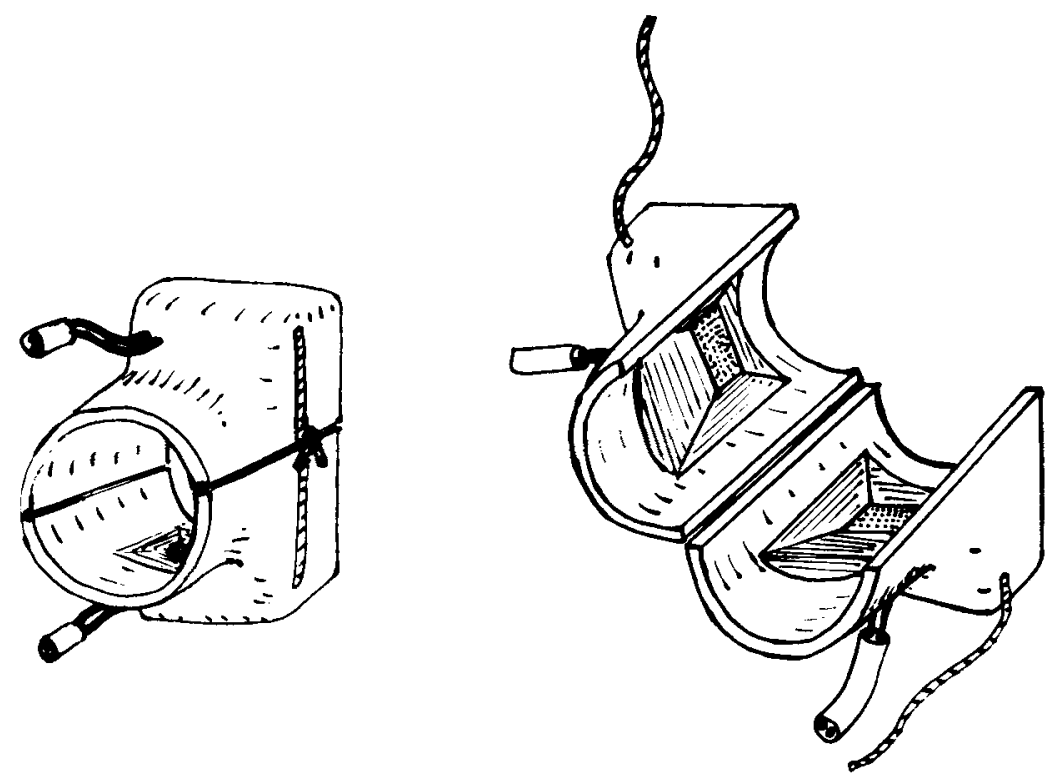

Figure 8. Drawing of Doppler ultrasonic flow probe showing piezoelectric crystals mounted in light plastic. (Parks Electronics. Beaverton, Oregon). H. James Rhodes, M.Sc.del.

Adams $e t a l^{6}$ following their investigation of the actions of succinylcholine in cats, concluded that the drug had both nicotinic and muscarinic properties and that a transient hypotension was common following its administration.

Wahlin ${ }^{2}$ using a drop counting method of blood flow measurement devised by Lindgren ${ }^{8}$ observed a fall in superior mesenteric artery blood flow following succinylcholine administration. He felt that this fall might have been associated with contraction of intestinal musculature.

Grandberg and Wahlin ${ }^{9}$ in a study of renal function, using inulin and $\mathrm{PAH}$, concluded that succinylcholine produced a fall in renal blood flow which they attributed to a direct effect of the drug upon the renal vessels.

Galindo and Davis ${ }^{10}$ showed in their study on succinylcholine and cardiac excitability that the drug increases serum potassium, produces post ganglionic sympathetic stimulation and direct myocardial stimulation.

In a comprehensive review and study of the subject Graf et al. ${ }^{11}$ found 63 references indicating that succinylcholine is associated with the production of arterial hypertension, 16 references indicating the opposite effect (namely hypotension) and 5 references showing a biphasic response (hypertension followed by hypotension). The results of their own study showed that the circulatory response to succinylcholine probably consisted of an increase in cardiac output and increased arterial blood pressure, partly counteracted by dilatation of resistance vessels (particularly in skeletal muscle). They emphasized the wealth of conflicting statements in the literature concerning the cardiovascular actions of this drug. 
The present experiments would appear to show that, in the dog, under the conditions of general anaesthesia produced and maintained as has been described, the administration of succinylcholine is followed by a standard, short-lived response.

Since the fall in arterial blood pressure which is noted is not accompanied by a change in cardiac output, this response to succinylcholine must be presumed to be the result of action on the peripheral vasculature.

Ganglionic vagal blockade and adrenergic receptor blockade fail to prevent the response to succinylcholine, indicating that this response is not mediated through the autonomic nervous system, nor is it the reflex result of possible circulatory changes elsewhere.

Since atropine blocks the response completely it would appear that succinylcholine produces the effects which have been observed by action upon muscarinic receptors in the peripheral vasculature.

As far as the renal circulation is concerned, the fall in blood flow which has been observed may be attributed to an increase in renal vascular resistance or to a decrease in resistance in some other organs or tissues with, perhaps, no change in the resistance of renal vessels.

It is difficult to explain an overshoot phenomenon which is demonstrable in the presence of ganglionic blockade and removed by adrenergic receptor blockade.

The effect of succinylcholine upon the renal circulation specifically is currently under investigation and will form the subject of a later report.

\section{SUMMARY}

Twenty-two mongrel dogs were employed for an investigation of the circulatory actions of succinylcholine in the presence of nitrous oxide, halothane anaesthesia.

A consistent response was obtained. Arterial blood pressure and renal blood flow fell and cardiac output either remained steady or rose slightly.

This response was obtunded by atropine but not by vagal ganglionic blockade nor by adrenergic receptor blockade.

It is felt that this response is the result of the actions of succinylcholine upon peripheral vascular muscarinic receptors.

Further studies on the renal and other vascular systems are to be undertaken.

\section{ACKNOWLEDGEMENTS}

My thanks are due to the following for help and advice: Dr. K. L. MacCannell, Professor and Head, Department of Pharmacology, University of Calgary, Calgary, Alberta; Dr. M. C. Sutter, Dr. H. D. Sanders, Associate Professors, Department of Pharmacology, University of British Columbia, Vancouver; Dr. L. C. Jenkins, Professor and Head, Department of Anaesthesia, University of British Columbia, Vancouver and Mrs. B. L. Koth and Mr. Donald Teiser.

The Fluotec vaporiser was kindly supplied by Ayerst, McKenna and Harrison and Co. Ltd., Montreal, P.Q. 


\section{RÉSUMÉ}

On a utilisé 22 chiens mongrel pour faire une étude sur les effets de la succinylcholine sur le système circulatoire au cours de l'anesthésie au protoxyde d'azote halothane.

Une conclusion assez intéressante a été obtenue. La pression du sang artériel et le débit sanguin du rein ont diminué alors que le débit cardiaque est resté stationnaire ou a légèrement augmenté.

Ce résultat a été atténué par l'atropine mais non par blocage ganglionnaire vagal ni par blocage des récepteurs adrénergiques.

Il semble que cette réponse résulte des effets de la succinylcholine sur les récepteurs muscariniques vasculaires périphériques.

\section{REFERENCES}

1. Belleville, J. W., \& Weaver, C. S. (eds.) Techniques in Clinical Physiology. CollierMacmillan (1969).

2. Barnett, G. L., \& JAckson, W. D. Measurement of instantaneous blood flow. Progress in Cardiovascular Diseases 5: 543 (196:3).

3. BAIN, W., \& HARPER, M. (eds.) Blond flow through organs and tissues. International Conference on Blood Flow Through Tissues and Organs. Glasgow. E. S. Livingstone: Edinburgh and London (1968).

4. Frankin, D. L. et al. Technique for radio telemetry of blood-fow velocity from unrestrained animals. Am. J. Med. Electronics 5: 24 (1966).

5. Goodman, Louis, \& Gilman, Alfred. The Pharmacological Basis of Therapeutics. Macmillan (1965).

6. Adams, A. K., \& HaLL, L. W. An experimental study of the actions of suxamethonium on the circulatory system. British Journal of Anaesthesia, 34: 445 (1962).

7. Wahlin, Aкe. The actions of succinylcholine on the peripheral blood vessels of the cat. Acta anaesth. Scand. 4: 21 (1960).

8. LindGren, P. An improved method for drop recording of arterial or venous blood flow. Acta physiol. Scand. 42: 5 (1958).

9. Grandberg, P. O., \& Wartix, AKe. The actions of succinylcholine on renal function. Acta anaesth. Scand. 6:201 (1962).

10. Galindo, A. H., \& Davis, T. B. Succinylcholine and cardiac excitability. Anesthesiology 32: 32 (1962).

11. Graf, K.; Ström, G. Wakrlex; Ake. Circulatory effects of succinylcholine in man. Acta Anesth. Scand. Suppl. 14: 1-48 (1963). 